\title{
Historical, Philosophical, and Legal Foundations of Strict Liability in Hugo Grotius-Some Introductory Remarks to the Special Dossier
}

\author{
Bart Wauters \\ IE Law School / IE University, Segovia-Madrid, Spain \\ bart.wauters@ie.edu
}

Present-day scholarship on the law of delicts (or the law of torts) can be broadly divided into two 'camps.' ${ }^{1}$ The first group of theorists manages a consequentialist conception: the system of delictual liability is modelled in view of the consequences it yields. Since the work of Ronald Coase, Guido Calabresi, and Richard Posner, these consequences are often seen in economic terms. The costs of accidents are externalities; the prevention of those externalities also leads to costs. It is the role of the law of delicts to force injurers and victims to take these costs into account and/or allow them to adjust their level of behavioural activity. The overall result is wealth maximisation. The second group of theorists favours a non-consequentialist or 'moral' approach. This is not to say that an economic analysis is not 'moral'; there is a sense in which wealth maximisation is the embodiment of the moral requirement of putting resources to their highest use. At the very least, as Posner emphasises, wealth maximisation is perfectly consistent with most influential moral systems. ${ }^{2}$ Rather, the 'moral' or non-consequentialist approach starts the analysis from the general idea that wrongdoing or unjustified conduct underlies liability. ${ }^{3}$

Strict liability is easily incorporated into a consequentialist or economic conception as it builds upon the kind of cost-benefit analysis the Learned Hand

1 Gregory C. Keating, 'Strict Liability Wrongs', in: Philosophical Foundations of the Law of Torts, ed. by John Oberdiek (Oxford: Oxford University Press, 2014), pp. 292-311 (pp. 292-4).

2 Richard A. Posner, 'Wealth Maximization and Tort Law: A Philosophical Inquiry', in: Philosophical Foundations of Tort Law, ed. by David G. Owen (Oxford: Oxford University Press, 1995), pp. 99-111 (p. 111).

3 A still-useful overview of tort scholarship until the end of the twentieth century is provided by David G. Owen, 'Foreword. Why Philosophy Matters to Tort Law', in Philosophical Foundations of Tort Law, pp. 1-27. 
formula offered for negligence. ${ }^{4}$ Strict liability sets a price for all the accidents attributable to the injurer's activities, not only for those accidents that should have been avoided. From a non-consequentialist perspective, strict liability is much harder to incorporate into a system of delictual liability, since it is difficult to identify wrongdoing when there has been compliance with standards of care. Even if a wrongdoing can be identified in instances of strict liability, such as the infringement of the obligation not to harm, the infringement of autonomy rights, or the infringement of the duty to compensate harm, this may lead to a further question: if the grounds for liability involve a wrongdoing, does it make sense to distinguish between fault-based and strict liability?

A historical inquiry of non-consequentialist conceptions of strict liability has not been systematically undertaken. ${ }^{5}$ This is entirely forgivable; within the rich history of the law of delicts overall, strict liability occupies marginal space. Historical sources do not even present a consensus about the use of the term 'strict liability', which is used in this dossier as a present-day category for many different types of 'torts'. But there are also more substantial grounds to ignore the historical non-consequentialist grounds for strict liability. The Roman emperor Justinian distinguished between four types of obligations: contracts, delicts, 'quasi-contracts' (broadly what would now be called unjust enrichment), and the 'quasi-tort' (quasi maleficium). It is in this last category that Justinian's compilers placed cases of liability without fault. Principled reflection on fault-less liability was picked up by the medieval canonists who focused rather on the relation between culpa and $\sin ^{6}{ }^{6}$ and by the late scholastics, especially. Just like Hugo Grotius did later, they accepted the existence of strict liability based on positive law. However, most of them did not find any

4 The Learned Hand formula says that if $\mathrm{B}<\mathrm{P} * \mathrm{~L}$ the defendant is negligent if he failed to take precautions, whereby B stands for the cost of those precautions, $\mathrm{P}$ for the probability that an accident occurs and $\mathrm{L}$ the magnitude of the harm. For context, see Steven Shavell, The Economic Analysis of Accident Law (Cambridge, MA: Cambridge University Press, 1987), p. 19; Richard A. Posner, Economic Analysis of Law (9th edn, Aspen Publishers, 2014), 6.1.

5 Useful information on the concept of strict liability in a comparative and historical perspective can be found in Reinhard Zimmermann, The Law of Obligations. Roman Foundations of the Civilian Tradition (Oxford: Oxford University Press, 1996), pp. 1095-1142; James Gordley, The Jurists. A Critical History (Oxford: Oxford University Press, 2013), passim; Eric Descheemaeker, The Division of Wrongs. A Historical Comparative Study (Oxford: Oxford University Press).

6 See the contributions of Jan Hallebeek, 'Negligence in Medieval Roman Law' and Harry Dondorp, 'Crime and Punishment. Negligentia for the Canonists and Moral Theologians' in Negligence. The Comparative Legal History of the Law of Torts, ed. Eltjo J.H. Schrage (Berlin: Duncker \& Humblot), pp. 73-100 and pp. 101-28; Stephan Kuttner, Kanonistische Schuldlehre von Gratian bis auf die Dekretalen Gregors IX. Systematisch auf Grund der handschriftlichen Quellen dargestellt (Città del Vaticano: Biblioteca Apostolica Vaticana, 1935). 
natural law or deontological grounds for it, or did so at the expense of reading fault into instances of strict liability.

To contribute to the discussion on the historical and philosophical foundations of the topic at hand, this special dossier presents four studies on the legal and philosophical traditions that have informed Grotius's thinking on instances of strict liability. Grotius accepts that positive law can impose forms of strict liability. The law can do so for reasons of proof or public utility. ${ }^{7}$ This seems to be a rather consequentialist point of view. As for moral considerations of Grotius's conception of strict liability, Joe Sampson's analysis of Thomas Aquinas and the Thomist tradition leads him to the conclusion that, for Grotius, it was difficult to think of liability outside a framework of fault. Therefore, on Grotius' own terms, instances of strict liability are an anomaly. 8 The practice-driven legal consilia and juridical treatises from the Low Countries around the year 160o, analysed by Wouter Druwé, reveal a dominant trend among Grotius' contemporary Netherlandish jurists to read a presumption of fault into instances of strict or 'qualitative' liability. In a sense, they were the inheritors of the jurists and canonists of the medieval ius commune. ${ }^{9}$ James Gordley contends that if strict liability can be explained on non-consequentialist grounds, it can be done on the basis of Aristotelian ideas of equality and commutative justice between parties. ${ }^{10}$ My own reading of Grotius has been informed by his conception of the right of necessity and by Kantian interpretations of strict liability, which claim that in some instances, consent to an institutional framework cannot be presumed unless its design has preserved equal freedom of all, with features such as the right of necessity or pockets of strict liability. ${ }^{11}$

This special dossier in Grotiana publishes the papers presented and discussed during a workshop convened at the IE Law School in Madrid, Spain on 10 January 2020. My gratitude goes out to the speakers at the workshop: James Gordley (Tulane Law School), Joe Sampson (Oxford University) and Wouter Druwé (KU Leuven). I am also grateful for Soledad Atienza and Marie-José Garot, who are now the dean and vice-dean of IE Law School; for Francisco de Elizalde, chair of legal studies at IE Law School and coordinator of the Jean

$7 \quad I B P$, II.17.21; Inleidinge, III.38.22.

8 Joe Sampson, 'The Place of Fault in Grotius' Conception of Liability for Wrongdoing', infra. See also his discussion on strict liability in the work of Aristotle and Aquinas in Joe Sampson, The Historical Foundations of Grotius' Analysis of Delict (Leiden: Brill, 2018), p. 119 and 16o.

9 Wouter Druwé, 'Qualitative liability in the Early Modern Low Countries (ca. 1425-1650)', infra.

10 James Gordley, 'Culpa Levissima and the Eclipse of Strict Liability', infra.

11 Bart Wauters, 'Strict Liability and Necessity in Grotius, Pufendorf, Smith, Kant, and Beyond', infra. 
Monnet Module 'Legal Liability of Robots'; for Annet Guevara of the IE Research Office; for Randall Lesaffer, president of the Grotiana Foundation; and finally, for Hans Blom, editor-in-chief at Grotiana. The workshop was co-funded by the Erasmus+ Programme Jean Monnet Activities of the European Union, 'Legal Liability of Robots: A European vision for a new legal regime'.

The strategy of the workshop and the papers published in this dossier do not aim to be comprehensive. Interest in the historical evolution of the philosophical foundations of strict liability is still at an early stage. But taken together, the four papers do offer a contextual (historical, philosophical, legal) framework for interpreting Grotius's conception of strict liability. It is hoped that this dossier will make a modest contribution to paying greater attention to the historical evolution of liability without fault. 